Received 06.05.2017 Reviewed 06.07.2017 Accepted 30.08.2017

A - study design

B - data collection

C - statistical analysis

D - data interpretation

$\mathbf{E}$ - manuscript preparation

F - literature search

\title{
Drought and water mobilization in semi-arid zone: The example of Hammam Boughrara dam (North-West of Algeria)
}

\author{
Hayat ADJIM $^{\mathrm{ABCDEF} \otimes}$, Abdelkader DJEDID $^{\mathrm{AF}}$
}

University Abou Bekr Belkaid, Faculty of Technology, BP 230, 13000 Tlemcen, Algeria; e-mail: h_adjim@yahoo.fr, a_djedid@yahoo.fr

For citation: Adjim H., Djedid A. 2018. Drought and water mobilization in semi-arid zone: The example of Hammam Boughrara dam (North-West of Algeria). Journal of Water and Land Development. No. 37 p. 3-10. DOI: 10.2478/jwld-2018-0019.

\begin{abstract}
The dam of Hammam Boughrara is an embankment dam built in a transboundary basin, between Algeria and Morocco; it was type-approved and delivered in 1998. This dam was supposed to solve the lack of drinking water in Oran (Algeria's second largest city) and enhance the agricultural perimeter of the area. It should regulate an annual water volume of 59 million $\mathrm{m}^{3}$. However, the northwest Algeria has experienced a fairly severe drought since the $80 \mathrm{~s}$. This article aims to show the impact of this drought on the amount of surface water that can be mobilized by this dam. The rainfall series recorded at four stations, located within the basin of the dam, were examined using the proportional deviation from the average, the running average, the frequency analysis, the Pita's index and the standardized precipitation index. These methods have shown a significant decrease of rain, starting from the hydrological year 1975/1976. These same approaches were also used to analyse series of flows spread over a longer period. This fact revealed three periods of drought which are 1940-1945, 1955-1967 and the most recent one highlighted by the rainfall series, starts at the year 1975/1976. The regularized water volume of the dam, calculated from the series of flow rates, is around 37 million $\mathrm{m}^{3}$. This value reflects a deficit of $40 \%$ of the regularized volume predicted by the designers of the dam.
\end{abstract}

Key words: drought, rainfall, regularized volume, semi-arid zone, statistical tests, water mobilization

\section{INTRODUCTION}

In the period of 1980-1990, Algeria was confronted to a serious water shortage which constrained the authorities to radically reorient the long and medium terms of the country water strategy management. Hence, the seawater desalination option was selected [KEHAL 2001; KETTAB 2001]. For the short term, all the dams which were under study started to be realized, and Hammam Boughrara dam emerged in this context. This embankment dam, built within the north western watershed of Wadi Tafna, drains a basin divided between Algeria and Morocco. This dam has a capacity of 177 million $\mathrm{m}^{3}$ and is supposed to regularize an annual volume of 59 million $\mathrm{m}^{3}$ [COBA
2001]. The realization of this dam was supposed to develop agricultural schemes in the region and supply lacks of drinking water to the city of Oran.

This paper intends to study the impact of the drought that was experienced in northwest Algeria [GHENIM, MEGHNOUNIF 2013; MEDDI et al. 2009; MedDi, MedDi 2009; MedEJERB, HeNIA 2011] on the quantity of surface water that can be mobilized by the dam of Hammam Boughrara.

Ten rainfall stations are located either inside or on the periphery of the basin of this dam. A review of all these stations records showed that only four of these ten stations are interesting for this study. These four stations are the only ones that have continuous and fairly long rainfall data series. Different techniques 
were used to determine the disruptions in these series. First, the cumulative rainfall index and the moving average were utilized. To confirm the results obtained, we used statistical tests such as the rank correlation test and Pettit test, as well as Lee and Heghinian's procedure and Buishand's procedure, and finally the segmentation technique of Hubert [BARBULESCU, DEGUENON 2014; HuBERT et al. 1989; KANG, YUSOF 2012; MRAD et al. 2013].

We also used the frequency analysis techniques as well as Pita's drought index, recommended for the Mediterranean region [BERGUAOUI 2001] and the standardized precipitation index $(S P I)$ recommended by the World Meteorological Organization [WMO 2012; 2016].

To complete the study, we used the series of Wadi Tafna flow rates between the years1925/1926 and $1983 / 1984$; this wadi is the main tributary of Hammam Boughrara dam. To this series, we applied the Cumulative deviation from mean and the moving average [BERGUAOUI 2001; KETTAB 2001].

\section{MATERIALS AND METHODS}

\section{PRESENTATION OF THE ZONE OF STUDY}

The dam of Hammam Boughrara is built in a semi-arid zone. It mobilizes surface waters from an Algerian-Moroccan transboundary basin. The total area of that basin is $2914 \mathrm{~km}^{2}$ (Fig. 1), $2000 \mathrm{~km}^{2}$ related to Wadi Mouilah $\left(1240 \mathrm{~km}^{2}\right.$ in Morocco and $760 \mathrm{~km}^{2}$ in Algeria) and $914 \mathrm{~km}^{2}$ to Wadi Tafna (in Algeria).

Wadi Mouilah is the main tributary of the dam of Hammam Boughrara; it drains the western part of the basin. This river starts in Algeria and penetrates into the Moroccan territory where it is known under the name of Wadi El Himer. Downstream of its junction with Wadi Isly, at the west of the city of Oujda, it takes the name of Wadi Bounaim. The downstream part of this river belonging to the Algerian territory is

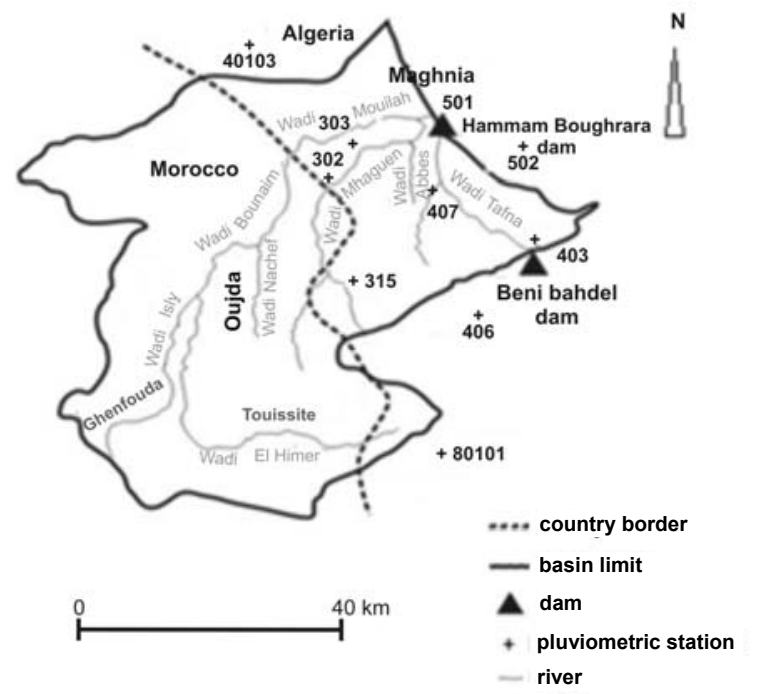

Fig. 1. Watershed of Hammam Boughrara dam; source: own elaboration known under the name of Wadi Mouilah (Fig. 1). The water of Wadi Tafna originates in the mountains of Tlemcen. The upstream of this wadi is retained by Beni Bahdel dam. Water from the basin, downstream of Beni Bahdel dam is mobilized by Hammam Boughrara dam.

\section{PRESENTATION AND ASSESSMENT OF PLUVIOMETRIC AND HYDROMETRIC DATA}

As stated before, ten stations record the information about the watershed of the dam of Hammam Boughrara: five stations are located within the basin area and the five others are in the surroundings.

By examining the precipitation series at these stations, we note that only four stations are interesting for this study because they have continuous and fairly long rainfall series. These stations are shown in Table 1; the stations of Maghnia, Beni Bahdel and Hammam Boughrara have continuous rainfall series until 2010/2011. For the station of Sabra, data are lacking for about 27 years, so only the period from 1970/1971 to $2009 / 2010$ was retained.

The observation period of water flows feeding the dam of Hammam Boughrara extends from 1925/1926 to $1983 / 1984$.

The rainfall record data used in this study was provided by the National Agency for Water Resources (Fr. Agence Nationale des Ressources Hydrauliques ANRH) while the flow rate series were taken from the study report on Hammam Boughrara dam [COBA 2001].

Table 1. Pluviometric stations that record rainfall data in the basin of Hammam Boughrara dam

\begin{tabular}{|l|c|c|c|}
\hline Station name & Code & $\begin{array}{c}\text { Station } \\
\text { localisation }\end{array}$ & $\begin{array}{c}\text { Observation } \\
\text { period }\end{array}$ \\
\hline Maghnia F & 302 & inside the basin & $1972 / 1973-2010 / 2011$ \\
\hline BeniBahdel & 403 & inside the basin & $1939 / 1940-2010 / 2011$ \\
\hline $\begin{array}{l}\text { Hammam- } \\
\text { Boughrara }\end{array}$ & 501 & inside the basin & $1969 / 1970-2010 / 2011$ \\
\hline Sabra & 502 & $\begin{array}{c}\text { peripheral } \\
\text { to the basin }\end{array}$ & $\begin{array}{c}1914 / 1915-1942 / 1943 \\
1970 / 1971-2009 / 2010\end{array}$ \\
\hline
\end{tabular}

Source: own study.

\section{CHARACTERIZATION OF DROUGHT}

\section{The proportional deviation from the mean}

Several indices are proposed in the literature to characterize drought. The simplest is the rainfall index given by:

$$
I p_{i}=\frac{P_{i}}{P_{m}}
$$

Where: $P_{i}=$ the rainfall in the year, $I$ and $P_{m}$ are the average inter-annual rainfall.

A year is dry if the index is less than unity, otherwise, it is humid.

In this study, we used the proportional deviation from the mean expressed as: 


$$
E p_{i}=I_{p i}-1
$$

The rainfall accumulation index, in successive years, allows identifying the major trends of rainfall variation.

\section{The moving average}

Moving averages are statistical tools to eliminate the transient fluctuations and highlight the medium and long term trends. To characterize the drought in the dam of Hammam Boughrara, the Manning lowpass filter [ASSANI 1999] is used to estimate the average value over three years. This odd centred filter allows writing the weighted moving average $\mathrm{Mm}_{i}$ of year $i$ as follows:

$$
M m_{i}=0.25 P_{i-1}+0.5 P_{i}+0.25 P_{i+1}
$$

\section{Frequency analysis}

The characterization of drought, using the frequency analysis, consists in adjusting the rainfall records according to a normal distribution and dividing the quantiles into classes. When the quantiles are divided in three, five or ten classes, it is then said that tertiles, quintiles or deciles methods were used.

Given the similarities between these methods, we used only the method of quintiles in this study. The series of data were then divided in five classes: very wet, wet, normal, dry and very dry.

\section{Pita's index}

PITA [2000] proposed an index which was meant to be adapted to the Mediterranean regions. It allows reporting on the accumulated monthly rainfall deficit. To calculate this index, the anomaly of the month $i$ is first calculated. It is defined as:

$$
A p_{i}=P_{i}-P_{M E D}
$$

Where: $P_{i}$ and $P_{M E D}=$ respectively the rainfalls in month $i$ and the median of the series corresponding to month $i$.

The cumulative anomaly of month $i\left(A P A_{i}\right)$ is then calculated by summing all negative monthly anomalies until a positive cumulative anomaly is reached. This calculation is repeated until the end of the rainfall series under study is reached.

Finally, the Pita's index $\left(I S S P_{i}\right)$ is calculated by standardizing the cumulative anomalies using the formula:

$$
I S S P_{i}=\frac{A P A_{i}-\overline{A P A}}{\sigma_{A P A}}
$$

Where: $\overline{A P A}$ and $\sigma_{A P A}$ are respectively the mean and the standard deviation of the cumulative anomalies of all months of the series.

\section{Standardized precipitation index SPI}

The standardized precipitation index is the result of McKee's research work carried out in 1993 [MCKeE et al. 1993]. It was recommended by the World Meteorological Organization (WMO) in 2009 as the main meteorological drought index that countries should use to monitor and follow drought conditions [WMO 2016].

This index is used to characterize the drought events in different regions in the world [BAK, LABĘDZKI 2014; IMANOV et al. 2012; JEMAI et al. 2016; JOUILIL et al. 2013; KHEZAZNA et al. 2017]. It may be utilised for monitoring both dry and wet conditions [DJELLOULI et al. 2016].

The standardized precipitation index SPI is defined as:

$$
S P I=\frac{P i-P m}{\sigma}
$$

Where: $P i=$ the annual rainfall $(\mathrm{mm}), P m=$ the mean rainfall $(\mathrm{mm}), \sigma=$ standard deviation.

This index may be calculated for multiple time scales. Negative $S P I$ values correspond to a precipitation deficit while positive values indicate a rainfall excess [JEMAI et al. 2016].

A drought event occurs any time the $S P I$ is continuously negative and reaches an intensity of -1.0 or less. The event ends when the SPI becomes positive [WMO 2012]. The severity of drought is identified according the classification scheme given in Table 2.

Table 2. Classification of drought severity based on SPI

\begin{tabular}{|c|c|}
\hline$S P I$ value & Class \\
\hline$S P I \geq 2.00$ & extremely wet \\
\hline $1.50 \leq S P I<1.99$ & severely wet \\
\hline $1.00 \leq S P I<1.49$ & moderately wet \\
\hline$-0.99 \leq S P I<0.99$ & near normal \\
\hline$-1.49 \leq S P I<-1.00$ & moderately drought \\
\hline$-1.99 \leq S P I<-1.50$ & severely drought \\
\hline$S P I \leq-2.00$ & extremely drought \\
\hline
\end{tabular}

Source: JEMAI et al. [2016].

\section{Searching ruptures by statistical tests}

A rupture in a chronological series can be defined as a change in the probability distribution of this series. Several statistical methods were explored [LUBES et al. 1998] and some of them are commonly used. Here we are using tests developed, in Khronostat software, by Montpellier Institute for Research and Development. These tests are:

- The rank correlation test. This is a nonparametric rank test. It is known to be robust but does not provide the break date.

- Pettit's test. This is a rank test that derives from the Mann-Whitney's test. It is free and nonparametric. It is deemed to be robust and allows determining the termination date. It can detect only one single failure.

- Lee and Heghinian's procedure. The Bayesian procedure of Lee and Heghinian is a parametric approach that requires a normal distribution of the series. The method sets up an a posteriori probability distribution of the position in a time of change. 
If the distribution is unimodal, the break date is estimated by the mode.

- Buishand's procedure. This procedure refers to the same model and the same assumptions as the previous test. To this procedure is associated the Bois ellipse method in order to visualize any break dates.

- The Hubert segmentation technique. The principle of this technique consists in cutting the time series into pieces whose averages, relative to these pieces are significantly different when compared to Schiffe's test. This technique is well suited for searching multiple breaks in the time series.

\section{FLOW AND INTAKE}

\section{IN THE DAM OF HAMMAM BOUGHRARA}

The same statistical tests and analysis applied to the rainfall data have been used to analyse the data series of flows feeding the dam of Hammam Boughrara.

\section{RESULTS AND DISCUSSION}

\section{THE PROPORTIONAL DEVIATION FROM THE MEAN}

\section{Station of Beni Bahdel}

This station, which has the longest data records, experienced a first rainfall decline between the years 1939/1940 and 1945/1946 (Fig. 2). This decline was already pointed out by PARDE [1946] as a very severe drought. The second period of declining rainfall began in 1975/1976 and lasted until 2007/2008.

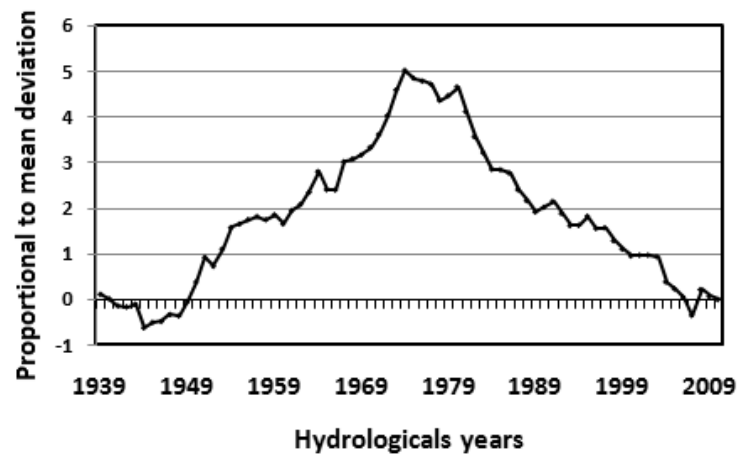

Fig. 2. Cumulative proportional deviation from the mean, at the station of Beni Bahdel; source: own study

\section{Stations of Hammam Boughrara, Maghnia and Sabra}

The stations of Hammam Boughrara, Maghnia and Sabra exhibit the same overall trends. The behaviour of the curves representing Maghnia and Sabra are similar to the curve given in Figure 3 which represents the station of Hammam Boughrara.

The above figure shows a short period of fluctuations between 1976/1977 and 1980/1981 followed by

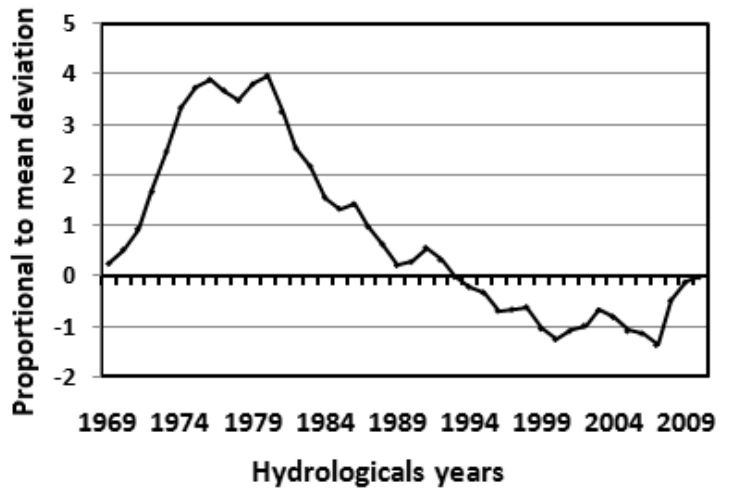

Fig. 3. Cumulative proportional deviation from the mean, at the station of Hammam Boughrara; source: own study

a continuous decrease of the precipitations until $2007 / 2008$. The return of light rains after this year (2007/2008) are also observed for the same period at the other three stations. This return of rain was also pointed out in 2013 by NOUACEUR et al. [2013].

\section{THE MOVING AVERAGE}

The application of the moving average (Eq. 3) to the stations of Beni Bahdel and Hammam Boughrara yielded the results shown in Figures $4 \mathrm{a}$ and $\mathrm{b}$. The values in these curves were centred-reduced for an easier reading.

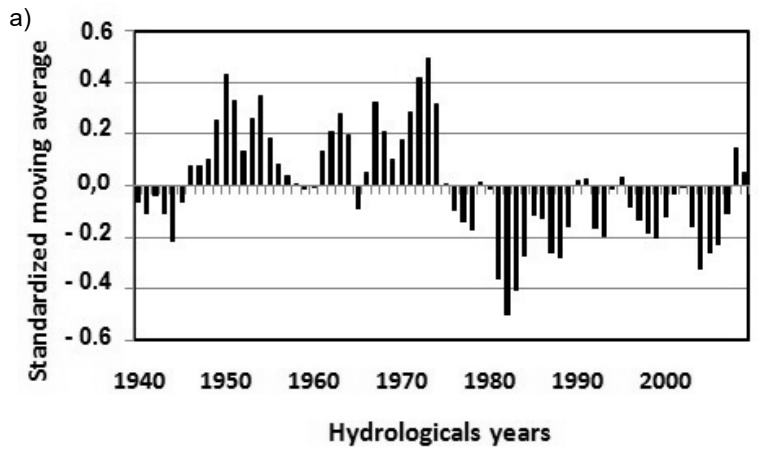

b)

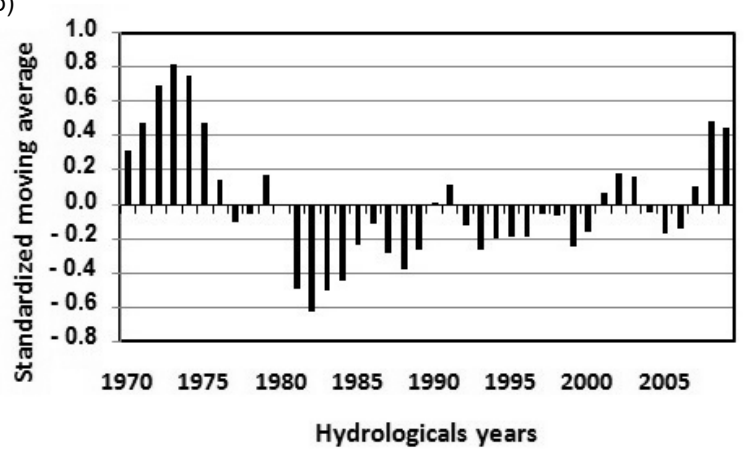

Fig. 4. Reduced-centred moving average, at the station of: a) Beni Bahdel, b) Hammam Boughrara; source: own study

According to Manning filter, the precipitations at the station of Beni Bahdel have gone through three phases (Fig. 4a): a first deficient phase between 1939/1940 and 1945/1946, a second excessive one 
between 1946/1947 and 1975/1976 and a third deficient one between 1976/1977 and 2007/2008. A return of light rains is observed starting from the year 2008/2009. The other three stations have recent data record which are nearly similar. The station of Hammam Boughrara (Fig. 4b) shows an excessive period that ends in 1976/1977, a dry period which starts from the year 1977/1978 and a return of light rains starting from the year 2007/2008. The results for the station of Maghnia and the station of Sabra are similar to those of Hammam Boughrara except for the existence of more fluctuation periods. Also, the return of light rains observed in the stations of Hammam Boughrara and Sabra are not detected in de station of Maghnia.

\section{FREQUENCY ANALYSIS}

To view the frequency analysis results, the numbers $2,1,0,-1$ and -2 are respectively assigned to very wet, wet, normal, dry and very dry periods. The results are depicted in Figure 5a for the station of Beni Bahdel. The averages of rainfall calculated for these five classes are 668.8, 527.3, 466.1, 391.6 and $284.3 \mathrm{~mm}$.

It is noticed that out of 28 years classified as dry and very dry, 21 years are in the period extending between 1975/1976 and 2007/2008. It is also noticed that for the 28 years classified as wet and very wet, only five years are in the period between 1975/1976 and 2007/2008.

The results for the stations of Maghnia and Sabra are similar to the results obtained for the station of Hammam Boughrara depicted in Figure 5b. The average values calculated over the five above mentioned
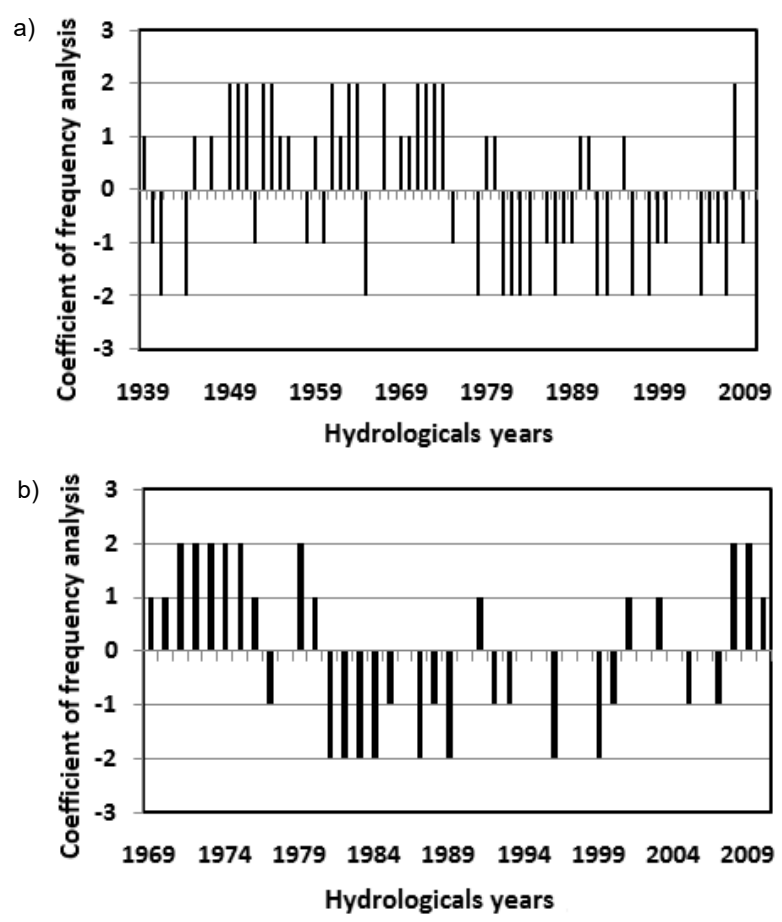

Fig. 5. Frequency analysis applied to the station of: a) Beni Bahdel, b) Hammam Boughrara; source: own study classes for Hammam Boughrara are 423.8, 318.8, 256.0, 196.3 and $130.2 \mathrm{~mm}$ and nearly the same values are obtained for the other remaining two stations.

In this figure, short-period fluctuations are found between 1976/1977 and 1980/1981 and then the rainfall drops continuously until the year 2007/2008. A return of only light rains are observed after $2007 / 2008$ for the four studied stations.

\section{PITA'S INDEX}

The application of Pita's index to the four stations of our study gave mixed results which are difficult to interpret. Nevertheless, it is noted that this index gives an overall trend which is similar to that given by the other methods, except that it is a bit harsh in its prognostications.

The variation of this index for the station of Hammam Boughrara is shown in Figure 6 where the results are rather consistent with those obtained by the other methods. It shows the existence of a period of excess rainfall before the year $1975 / 1976$ as stated by the other methods. There is also a sharp rainfall drop starting from the year 1981/1982 with the possible return of rain in 2008/2009.

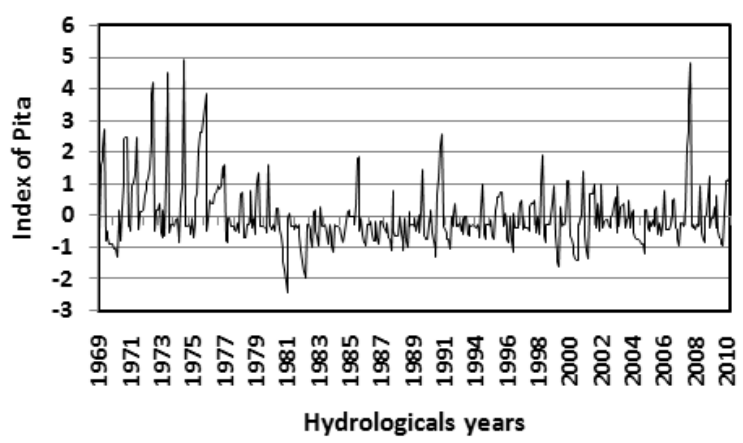

Fig. 6. Pita's index applied to the station of Hammam Boughrara; source: own study

\section{STANDARDIZED PRECIPITATION INDEX SPI}

The results of standardized precipitation index (SPI) method applied to the Beni Bahdel and Boughrara stations are shown in Figure $7 \mathrm{a}$ and $\mathrm{b}$. The graphs show that for both stations, there were two distinct periods, one before 1975 and the other between 1975 and 2010. The first period has a rather wet trend, whereas the second period is rather dry.

\section{Station of Beni Bahdel}

For the Beni Bahdel station, over the period $(1939 / 1940$ to $1974 / 1975)$ corresponding to the wet years, it is noted that on 36 years:

- only two years are considered dry or moderately dry (1944/1945 and 1965/1966) which represent 6\%;

- 23 years have near normal rainfall: 15 have a positive $S P I$ and 8 have a negative $S P I$;

- 11 years are considered moderately wet or severely wet. 

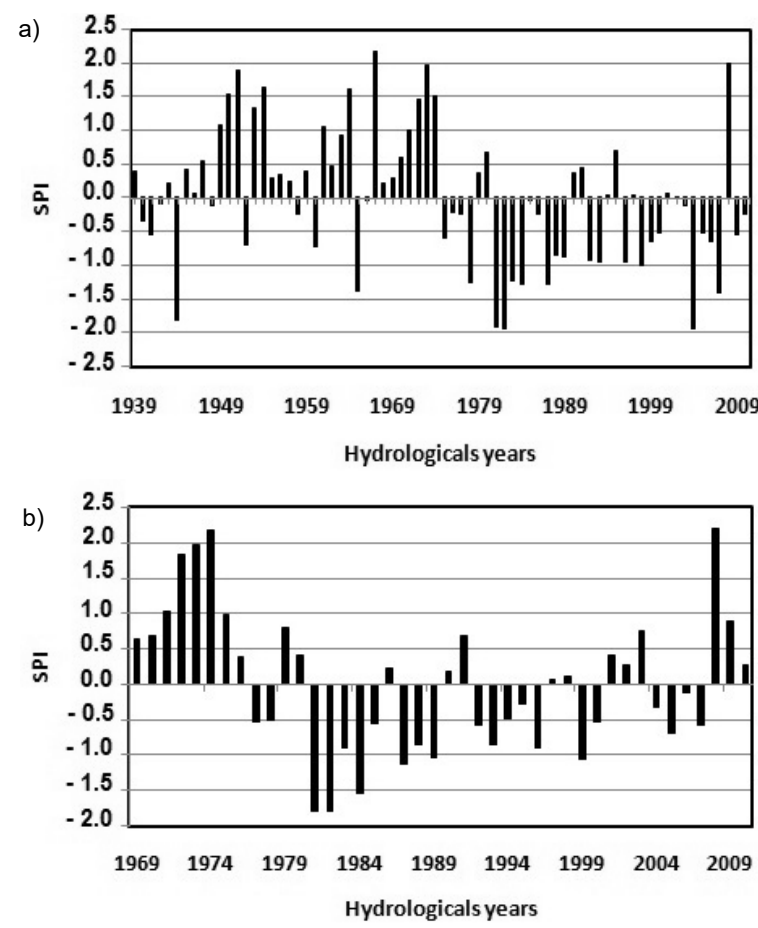

Fig. 7. Annual standardized precipitation index $S P I$ value in station of: a) Beni Bahdel, b) Hammam Boughrara; source: own study

So in this first period $72 \%$ of the $S P I$ values are positive and only $28 \%$ have negative values.

For the period corresponding to the dry years (1975/1976 to $2010 / 2011)$ and which is also spread over 36 years, it is noted that:

- only the year 2008 is considered severely wet;

- 9 years are considered dry or very dry, which corresponds to $25 \%$ of this second period;

- the remaining 26 years are in near normal class; of these 26 years, 17 have a negative $S P I$.

This states that over the whole of this second period, $72 \%$ of years have a negative SPI. While for the whole period studied (72 years), 49 years are considered to have near normal rainfall. If in the first period the dry and humid years are intercalated, in the second period the dry years follow each another, which indicates a drought settlement in the region.

\section{Station of Hammam Boughrara}

For the period before 1975, even though this period is short, since it covers only 6 years, the SPI values are all positive, indicating a rainy period during which four years are classified as wet to extremely wet, the remaining years are considered having a normal rainfall with positive value of $S P I$.

For the 36 years corresponding to the period 1975/1976-2009/2010:

- only one year (2008/2009) is classified as extremely wet;

- 29 years have a near normal rainfall among which 15 have a negative $S P I$;

- 6 years are considered moderately dry or dry. The years 1987/1988, 1989/1989 and 1999/2000 are considered as moderately dry while the years
$1981 / 1982,1982 / 1983$ and $1984 / 1985$ are considered as severely dry.

Thus, for the whole period studied, 21 years have a negative $S P I$ which is about $60 \%$ of the studied range.

The same trend is observed in this station and the Beni Bahdel station, since the dry years follow each other in the majority of time; that is to say that the drought settled after 1975.

\section{SEARCHING RUPTURES BY STATISTICAL TESTS}

When these statistical tests are applied to rainfall series, they give the following results.

- For the station of Beni Bahdel, break in the rainfall series is detected by all the tests. Similarly, all the techniques that detect the date, suggested the year $1975 / 1976$ as the beginning of the dry period.

- For the station of Hammam Boughrara, breaks are not rejected between 99 and $95 \%$, depending on the test used. Similarly, the beginning of the dry period is found to be the year 1980/1981 according to Pettit's test, while it is the year 1975/1976 for Lee and Heghinian procedure and for Hubert segmentation technique. This last technique detected a second break in 2007/2008, which means the return of rain, as previously mentioned.

- For the station of Maghnia, the tests used give the year 1980/1981 as the break date. There is a $90 \%$ lack of breaks according to Pettit's test, and 99\% according to the other tests.

- For the station of Sabra, the absence of breaks is rejected between 95 and $99 \%$. The break date is during the year 1981/1982 according to Pettit's test, and it is $1975 / 1976$ according to the others.

\section{FLOW AND IN TAKE}

\section{IN THE DAM OF HAMMAM BOUGHRARA}

The statistical tests did not detect any break in the series. The cumulative proportional deviation from the mean (Fig. 8) or the standard moving average (Fig. 9) indicate that these rain flows have experienced several variation cycles, but in general, there are drought periods such as those previously mentioned; i.e. from $1940 / 1941$ to $1945 / 1946$ and also the one that starts from the year 1975/1976.

By applying the chi-squared test, water flows adjust better to a log-normal distribution. This allowed finding a regularized volume of the dam equal to 36.87 million $\mathrm{m}^{3}$. This value is $40 \%$ lower than that provided by the designers of the dam, although the series of water flows does not cover the entire dry period.

The volumes mobilized by the dam between $1999 / 2000$ and 2007/2008, helped to confirm the above mentioned results. The maximum, minimum and average volumes mobilized over this period are 48.4, 11.6 and 30.3 million $\mathrm{m}^{3}$, respectively. These volumes are much lower than the dam design value of 59 million $\mathrm{m}^{3}$. 


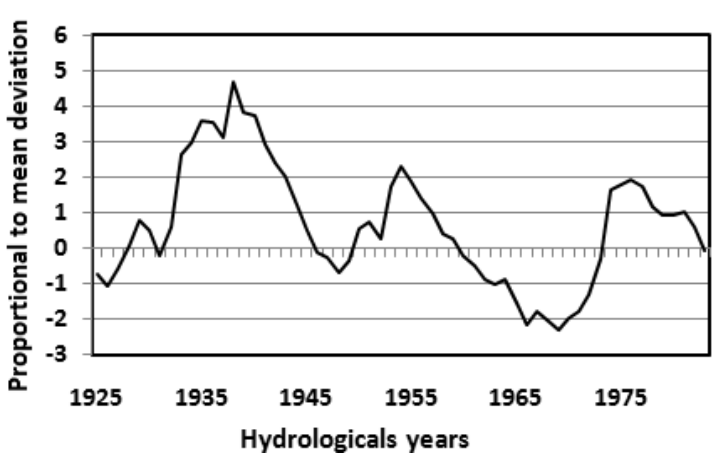

Fig. 8. Cumulative proportional deviation from mean of water flows of Hammam Boughrara dam; source: own study

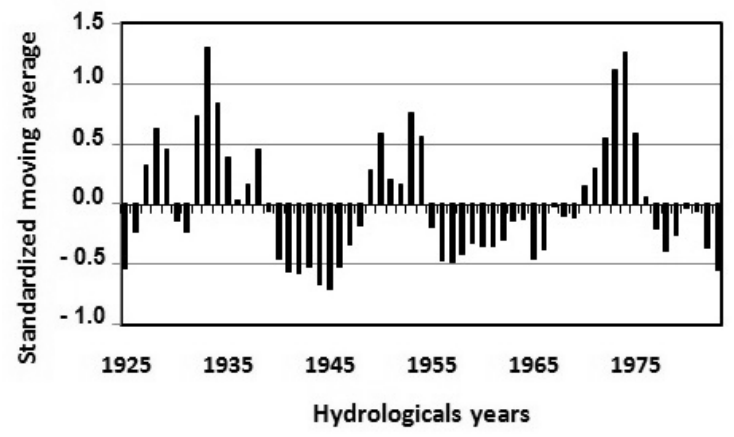

Fig. 9. Mobile average of water flows of Hammam Boughrara dam; source: own study

\section{CONCLUSIONS}

The present work focused on the dam of Hammam Boughrara. This dam, built in 1998, was realized for a better surface water mobilization program in the North-West of Algeria. The initial study indicated that this dam could annually regulate a volume of 59 million $\mathrm{m}^{3}$.

This paper shows that the basin rainfall of this dam has experienced a significant decrease starting from the year 1975/1976. This drop was confirmed by all the methods used in this study in the four pluviometric stations.

Beni Bahdel station which has data records starting from 1939/1940, showed two periods of drought; one from $1940 / 1941$ to $1945 / 1946$ and the other started in $1975 / 1976$.

The study of the mobile average of flow rates in the dam of Hammam Boughrara identified three drought periods; one from 1939/1940 to $1948 / 1949$, a second one from $1955 / 1956$ to $1969 / 1970$, and the third one started in 1975/1976. These dry periods appear to have a cyclical aspect more pronounced in recent years.

The volume of water regularized by the dam, obtained in this study, is around 37 million $\mathrm{m}^{3}$. This value is $40 \%$ lower than the value estimated by the designers of the dam.

Consequently, the dam of Hammam Boughrara cannot actually mobilize the water volume initially planned. It will be impossible to satisfy the drinking water needs and water requirements for irrigation in the region. By taking into account the growing water demand in the western region of Algeria, the policy of seawater desalination adopted, turns out to be fully justified, since it allows satisfying the needs of drinking water supply from the desalination of seawater and reserving the water mobilized by the dam Hammam Boughrara to promote agriculture in the region.

\section{Acknowledgements}

We are grateful to the ANRH services (National Agency of Hydraulic Resources) and ANBT (National Agency of Dams and Transfers) for providing us with the necessary data used for this study.

\section{REFERENCES}

ASSANI A.A. 1999. Analyse de la variabilité temporelle des précipitations (1916-1996) à Lumbashi (Congo-Kinshasa) en relation avec certains indicateurs de la circulation atmosphérique (Oscillation australe) et océanique (El Nino/La nina) [Analysis of the temporal variability of precipitation (1916-1996) in Lumbashi (Congo-Kinshasa) in relation to certain indicators of atmospheric circulation (Southern Oscillation) and oceanic]. Sécheresse.Vol. 10. No. 4 p. 245-252.

Barbulescu A., DeguenON J. 2014. Change points detection and models for precipitation evolution. Case study, Rom. Journal of Physics. Vol. 59. No. 5-6 p. 590-600.

BĄK B., ŁABĘDZKI L. 2014. Prediction of precipitation deficit and excess in Bydgoszcz Region in view of predicted climate change. Journal of Water and Land Development. No. 23 p. 11-19. DOI 10.1515/jwld-2014-0025.

Bergaoui M. 2001. Caractérisation de la sécheresse météorologique et hydrologique: cas du bassin versant de Siliana en Tunisie [Characterization of meteorological and hydrological drought: case of the Siliana watershed in Tunisia]. Sciences et changement planétaires/Sécheresse. Vol. 12. No. 4 p. 205-213.

COBA 2001. Barrage de Hammam Boughrara, etude d'impact sur l'environnement [Dam of Hammam Boughrara, environmental impact assessment]. Consultores de Engenharia e Ambiente. Vol. 1. Caractérisation du projet et de l'environnement [Characterization of the project and the environment] p. 3-58.

Djellouli F., Bouanani A., BaBA-Hamed K. 2016. Efficiency of some meteorological drought indices in different time scales, case study: Wadi Louza basin (NW-Algeria). Journal of Water and Land Development. No 31 p. 33-41. DOI 10.1515/jwld-2016-0034.

GHENIM A.N., MEGNOUNIF A. 2013. Ampleur de la sécheresse dans le bassin d'alimentation du barrage Meffrouche (Nord-Ouest de l'Algérie) [Extent of drought in the catchment area of the Meffrouche dam (North-West of Algeria)]. Géographie Physique et Environnement. Vol. 7 p. $35-49$.

Hubert P., Carbonal J.P., Chaouche A. 1989. Segmentation des séries hydrométriques - application à des séries de précipitations et de débits de l'Afrique de l'Ouest [Segmentation of hydrometric series - application to series of precipitation and flows of West Africa]. Journal of Hydrologie. Vol. 110 p. 349-367.

IMANOV F.A., MAMMADOV A.S., HASANOVA N.I. 2012. Investigation of droughts in the Lankaran region of Azerbaijan. Journal of Water and Land Development. No. 16 p. 11-15.

Jemai S., Ellouze M., Agoubi B., ABIDA H. 2016. Drought intensity and spatial variability in Gabes Watershed, southeastern Tunisia. Journal of Water and Land Development. No. 31 p. 63-72. DOI 10.1515/jwld-2016-0037. 
Jouillil I., Bitar K., Salama H., Amraoui A., MoKssit A., TAHIRI M. 2013. Secheresse meteorologique au basin hydraulique oum er rbia Durant les dernières decennies [Meteorological dryness at the hydraulic basin oum er rbia During the last decades]. Larhyss Journal. No. 12 p. 109-127.

KANG H.M., YUSOF F. 2012. Homogeneity tests on a daily rainfall series in Peninsular Malaysia. International Journal of Contemporary Mathematical Sciences. Vol. 7. No. 1 p. 9-22.

KEHAL S. 2001. Retrospectives et perspectives du dessalement en Algérie [Retrospectives and prospects of desalination in Algeria]. Desalination. Vol. 136 p. 35-42.

KeTTAB A. 2000. Les resources en eau en Algérie: strategies, enjeux et vision [Water resources in Algeria: Strategies, challenges and vision]. Desalination. Vol. 136 p. 25-33.

KheZAZna A., Amarchi H., Derdous O., Bousakhria F. 2017. Drought monitoring in the Seybouse basin (Algeria) over the last decades. Journal of Water and Land Development. No. 33 p. 79-88. DOI 10.1515/jwld-2017-0022.

LubeS-Niel H., MASSON J.M., PATUREL J.E., Servat E. 1998. Variabilité climatique et statistiques. Etude par simulation de la puissance et de la robustesse de quelques tests utilisés pour vérifier l'homogénéité de chroniques [Climatic variability and statistics. A simulation approach for estimating power and robustness of tests of stationarity]. Revue des Sciences de l'Eau. Vol. 3 p. 383-408.

MEDDI H., MEDDI M. 2009. Variabilité des precipitations annuelles du Nord-Ouest de l'Algérie [Variability of annual precipitation in northwestern Algeria]. Secheresse. Vol. 20. No.1 p. 57-65.

MedDi M., TAlia A., MARTIN C. 2009. Evolution recente des conditions climatiques et des écoulements sur le bassin versant de la Macta (Nord-Ouest de l'Algérie) [Recent changes in climatic conditions and flows in the Macta watershed (north-western Algeria)]. Géographie Physique et Environnement. Vol. 3 p. 61-84. DOI 104000/physiogéo. 686 .

MEDEJERB A., HENIA L. 2011. Variations spatio-temporelle de la secheresse climatique en Algérie Nord-Occidentale
[Climatic spatio-temporal variation in North-Western Algeria]. Courrier du savoir. No. 11 p. 71-79.

MCKeE T., DOESKEN N., KLEIST J. 1993. The relationship of drought frequency and duration to time scales. In: Proceeding of the eighth conference on applied climatology, Anaheim, California, 17-22 January 1993. Boston. American Metrological Society p. 197-184.

MRAD D., DAIRI S., DJEBBAR Y. 2013. Impact of climatic variability on the water resources in the catchment Seybouse [online]. Seventeenth International Water Technology Conference. 5-7 November 2013. Istanbul pp. 6. [Access 1.07.2017]. Available at: http://iwtc.info/wpcontent/uploads/2013/11/213.pdf

NouACEuR Z., LAignel B., TURKI I. 2013 Changements climatiques au Maghreb: Vers des conditions plus humides et plus chaudes sur le littoral algérien [Climate change in the Maghreb: Towards wetter and warmer conditions on the Algerian coast]. Géographie Physique et Environnement. Vol. 7 p. 307-323. DOI 10.4000/physio-geo. 3686.

PARDE M 1946. La sécheresse 1941-1945 [The drought of 1941-1945]. Annales de l'Université de Grenoble (France). Vol. 22. No. 3 p. $99-103$

PITA M.F 2000. Un nouvel indice de sécheresse pour les domaines méditerranéens. Application au bassin de Guadalquivir (Sud-Ouest de l'Espagne) [A new drought index for Mediterranean areas. Application to the Guadalquivir Basin (South-West of Spain)]. Publications de 1'Association Internationale de Climatologie. Vol. 113 p. 225-234.

WMO 2012. Standardized precipitation index user guide (M. Svoboda, M. Hayes and D. Wood). WMO-No. 1090. Geneva. World Meteorological Organization. ISBN 97892-63-11090-9 pp. 16

WMO 2016. 2016. Handbook of drought indicators and indices (M. Svoboda and B.A. Fuchs). Integrated Drought Management Programme (IDMP), Integrated Drought Management Tools and Guidelines. Series 2. Geneva. World Meteorological Organization (WMO) and Global Water Partnership (GWP). ISBN 978-92-63-11173-9, 978-91-8782324-4 pp. 45

\section{Hayat ADJIM, Abdelkader DJEDID}

\section{Susza i gromadzenie wód powierzchniowych w obszarach półsuchych; Przykład zapory wodnej Hammam Boughrara (w pólnocno-zachodniej Algierii)}

\section{STRESZCZENIE}

Zaporę Hammam Boughrara zbudowano na granicy Algierii i Maroka i uruchomiono w 1998 r. Zapora miała na celu rozwiązać problem braku wody pitnej w Oranie (drugim co do wielkości mieście Algierii) i zwiększyć zasięg rolnictwa w regionie. Miała regulować rocznie zasoby wody o objętości 59 milionów $\mathrm{m}^{3}$. Północnozachodnie regiony Algierii doświadczają jednak silnej suszy od lat osiemdziesiątych XX wieku. Artykuł ma wykazać wpływ tej suszy na ilość wody, która może gromadzić zbiornik. Serie opadowe notowane w czterech stacjach zlokalizowanych w zlewni zbiornika analizowano z wykorzystaniem proporcjonalnego odchylenia od średniej, ruchomej średniej, analizy częstości, wskaźnika Pity i wskaźnika standaryzowanego opadu. Stosowane metody wykazały istotne zmniejszenie ilości opadu począwszy od roku hydrologicznego 1975/1976. Takie samo podejście zastosowano do analizy serii szybkości przepływu, które obejmują dłuższy okres. Analiza ujawniła trzy okresy suszy, które przypadały na lata 1940-1945, 1955-1967 i ostatni wykazany przez serie opadów, który rozpoczął się w roku 1975/1976. Zasoby wody regulowane rocznie obliczone z serii przepływów wynoszą ok. 37 milionów $\mathrm{m}^{3}$. Ta ilość $\mathrm{w}$ istocie odzwierciedla deficyt gromadzonej wody, gdyż jest o $40 \%$ mniejsza niż objętość przewidywana przez projektantów zapory.

Słowa kluczowe: gromadzenie wody, opad, regulacja objętości, strefa półpustynna, susza, testy statystyczne 